\title{
Alfarabi y el rol de la poética
}

\author{
Luis Xavier López-Farjeat \\ Universidad Panamericana
}

Alfarabi ocupa un lugar central en la recepción árabe del Órganon aristotélico*. Al igual que otros comentadores, Alfarabi situó a la Retórica y a la Poética junto a los tratados analíticos, las Categorías, el Peri Hermeneias, los Tópicos y las Refutaciones Sofisticas. Su comprensión de la Poética es especialmente original. Leer la Retórica como un tratado de lógica no supone demasiados problemas, pues el propio Aristóteles señala cuáles son los silogismos que ha de utilizar un retórico. En cambio, estudiar la Poética con la intención de integrarla a la lógica, nos obliga a pensar en la posibilidad de un silogismo poético del que Aristóteles no habla en ninguna parte del corpus. Ha de advertirse, sin embargo, que aunque en la Poética no se utilizan los términos "silogismo poético", Aristóteles sí afirma que el mito permite razonar syllogizesthai (Poética 1448 b 13-20).

Como primera parte de este trabajo, ubico la Poética. dentro del Organon de acuerdo con la ordenación de los tratados que lo componen, según Alfarabi. Para ello, reviso algunas aportaciones de los alejandrinos que influyeron en el filósofo árabe y presento la clasificación de los tratados de lógica en una obra titulada Catálogo de las ciencias (Ihșā' al-'ulüm). Posteriormente, analizo las similitudes que Alfarabi establece entre retórica y poética al explicar su modo de operar en los Fusul [al- 'ilm] Al-Madani o Artículos de

\footnotetext{
* Agradezco las observaciones de Héctor Zagal, Vicente de Haro, María Fernández, María Elena García y Karen González. Elaborado con el apoyo del proyecto de investigación CONACYT 2002-C01-42166.
} 
la Ciencia Politica' ${ }^{1}$ Por último, me detengo en algunos aspectos del denominado 'silogismo poético' ('alqiyásul al š'riy'yun). Alfarabi reflexiona sobre la dimensión argumentativa de la poesía para mostrar la utilidad de los discursos que recurren a imágenes persuasivas.

Un estudio sobre la dimensión argumentativa de la poética nos lleva a plantear el tema ya aludido del silogismo poético. Es oportuno, desde ahora, apuntar la complejidad que implica esta clase de presunto silogismo. El tema es ambiguo, incluso en los intérpretes de Alfarabi. Fuad Said Hadad, por ejemplo, sostiene que, aunque Alfarabi habla de cinco artes lógicas y en ellas incluye a la poética, ésta no utiliza ninguna clase de silogismo. Por ello, señala, no es oportuno referirse a la poética como un arte silogístico. Es, mejor dicho, el arte de la comunicación. $Y$, en efecto, la comunicación puede ser asilogística ${ }^{2}$. Además, uno de los estudios más completos sobre la lógica farabiana, el de Joep Lameer, no menciona el silogismo poético ${ }^{3}$, aunque sí se refiere a la explicación de la analogía que aparece en el breve comentario de Alfarabi a los Analiticos Primeros. Por otra parte, como registra Salim Kemal, es verdad que en los Cánones del Arte Poético, Alfarabi sostiene que el discurso poético recurre a cierto tipo de silogismo ${ }^{4}$. En otro estudio, he defendido que el silogismo poético no aparece como tal porque se incluye en las denominadas "formas mixtas del silogismo". Esto significa que pueden darse combinatorias silogísticas. El ejemplo común es el discurso poético, pues en él se mezclan silogismos dialécticos, retóricos y sofisticos ${ }^{5}$. En su Carta introductoria a la

1 Utilizo la edición bilingủe de Rafael Ramón Guerrero, incluida en ALFARABI: Obras Filosófico- Politicas, Madrid: Debate CSIC 1992.

${ }^{2}$ Cf. FUAD SAID HADDAD: Alfarabi's Theory of Comunication, Lebanon: American University of Beirut 1989, pp. 117-119.

${ }^{3}$ Cf. LAMEER, J.: Alfarabi and Aristotelian Syllogistics, The Netherlands: E. J. Brill, Leiden 1994.

${ }^{4}$ Cf. Kemal, S.: The poetics of Alfarabi and Avicenna, The Netherlands: E. J. Brill, Leiden 1991, p. 108.

5 Cf. López- FarJeat, L. X., SÁnchez, M.: Analogia poética en Alfarabi, promanuscrito, 2002 (aparecerá publicado en 2004 en la Revista española de Filosofia Medieval). Éste es un trabajo en donde se apuntan algunos aspectos clarificadores sobre la analogia. Sin embargo, en ese desarrollo aún aparecen 
Lógica o Tratado con el que comienza el libro (Risālah sudira bihā al-kitāb), Alfarabi escribe:

Las artes son en parte silogisticas y en parte no-silogísticas. Las silogísticas son aquellas que, cuando sus partes están integradas y perfeccionadas, tienen como acción suya, en consecuencia, el uso de silogismo; mientras que las nosilogisticas son aquellas que, cuando sus partes están integradas y perfeccionadas, tiene como acción suya y fin, el hacer algún trabajo particular, tal como la medicina, la carpintería, la construcción, y otras artes que están designadas para producir algún trabajo o alguna acción. Ahora, las artes silogísticas son cinco: la filosofia, el arte de la dialéctica, el arte sofístico, el arte retórico y el arte de la poesia 6 .

Este texto debe comprenderse a la luz del Breve comentario a Analiticos Primeros en donde Alfarabi expresa con claridad lo que debe entenderse por silogismo. Ese trabajo funge como una especie de manual para comprender el silogismo. Por ello, en los distintos manuscritos y referencias que hay sobre él, recibe varios nombres: Breve tratado sobre el silogismo (Kitāb al-qiyās al sạghir), Breve compendio sobre la naturaleza del silogismo (Kitāb al-mukhtasar alsaghï fi-l-kaifiyyah al-qiyās); Breve compendio de lógica a la manera de los mutakallimūm o teólogos (Kitāb al-mukhtasar alsaghïr fi-l-mantiq'alā tariqah al- mutakallimūm). En este comentario puede reconocerse la influencia de personajes griegos como Alejandro de Afrodisia, especialmente, pero también de Porfirio, Temistio, Amonio, Filopón, Simplicio y Olimpiodoro. Gran

algunas ambiguedades en la definición del silogismo poético. Es verdad que puede haber formas mixtas de silogismo. No obstante, todo indica que Alfarabi piensa en algo mucho más sencillo que lo que hemos desarrollado en ese articulo y que para comprender el silogismo poético basta con apoyarse en la transferencia analógica descrita en el comentario breve a los Analiticos Primeros. Valga aquel articulo como una pieza intermedia en este proceso de desentrañar qué quiere decir Alfarabi cuando afirma que la poesia usa un tipo de silogismo.

${ }^{6}$ Utilizo la versión bilingue de DuNLOP, D. M. publicada como: Alfarabi is Introductory Risalah on Logic, The Islamic Quarterly 3, 1956-1957, p. 230. 
parte de los trabajos de estos filósofos fueron estudiados por los traductores sirios. En el pasaje 250:12-18 se define el silogismo:

Un silogismo es un cuerpo discursivo elaborado con premisas constituidas de tal modo que si se unen se sigue de ellas, esencialmente y no por accidente, otra más, algo distinto como resultado. Cualquier conocimiento al que se llega por el silogismo se denomina conclusión y consecuencia. Un silogismo está compuesto de premisas que se comprenden en alguno de estos "cuatro modos"? También podría estar compuesto de premisas que son conclusiones de otros silogismos cuyas premisas se reducen a la comprensión de alguno de estos "cuatro modos". Un silogismo. está, al menos, compuesto de dos premisas que tienen una "parte" (juz') común. Los silogismos pueden estar compuestos de premisas condicionales y de premisas categóricas.

Esta definición es similar a la aristotélica. Puede adelantarse que el silogismo poético del que se hablará más adelante se ajusta de un modo particular a esta estructura. En la sección ocho de este mismo comentario, Alfarabi estudia la inferencia por transferencia en donde se explica la analogía que, como estudiaremos, bien podría fungir como un silogismo poético. Aun asi, como mostraré, la peculiaridad del silogismo poético es que funciona como una analogía impropia, muy similar a la que actúa en un paradigma. Es esto lo que propondré hacia las últimas líneas.

\footnotetext{
7 Se refiere a los cuatro modos que han sido descritos en su breve comentario (250:2-10) y que corresponden, como hace notar RESCHER, N. (Short Commentary on Aristotle's Prior Analytics, traducción de N. Rescher, University of Pittsburgh Press 1963, n. 12, p.68), a los que se mencionan en Analíticos Primeros 24a23 y Tópicos 100a29, 101a12, 104a7 y 105a36: opinión común, opinión aceptada por la mayoría o por los más sabios, conocimiento sensorial y conocimiento evidente.
} 


\section{Retórica y Poética en el Órganon}

En uno de sus ya clásicos artículos, R. Walzer ${ }^{8}$ desarrolla el debate helénico y árabe sobre la inclusión de la Retórica y la Poética como parte de la lógica aristotélica. Walzer nos recuerda que la incorporación de esos tratados al Organon no fue una iniciativa de los árabes. Fueron los filósofos alejandrinos quienes habían establẹcido tiempo atrás esa clasificación: Amonio, Filopón, Elías y algunos otros.

En el comentario de Amonio a los Analíticos Primeros, por ejemplo, aparece un pasaje relevante al respecto:

Aristóteles dijo que hay tres especies de silogismo, el apodíctico, el dialéctico y el sofístico, y habló sobre el apodíctico en Analiticos Posteriores, sobre el dialéctico en Tópicos, y sobre el sofistico en Refutaciones Sofisticas. Pero, ¿dónde podemos clasificar la Retórica y la Poética? Aristóteles los entiende como tratados de lógica. Por supuesto debe decirse que es verdad que los tratados silogísticos son una cosa y los lógicos otra. De ser así, si podemos dividir los tratados silogísticos, debemos hacerlo, como hemos dicho, conforme a las tres especies de silogismos y, en estos dos saberes tentativos, los silogismos parecen los mismos que los sofisticos. (...) Y no debemos menospreciar la discusión sobre si la Retórica y la Poética son silogísticas. Porque si hiciésemos una división de la lógica la dividiríamos en silogística y asilogística; la silogística es la apodíctica, la dialéctica y la sofiștica; la asilogística es la métrica y la amétrica, la métrica sería la Poética, la amétrica la Retóricas.

${ }^{8}$ Cf. WALZER, R.: "Zur Traditionsgeschichte der Aristotelischen Poetik", en Greek into arabic: essays in islamic philosophy, Oxford: Oriental Studies number 1, Cassirer 1962.

${ }^{9}$ AMMONIUS: In Aristotelis Analyticorum priorum librum 1 commentarium, 11, 22 38, ed. M. Wallies, Commentaria in Aristotelem Graeca, vol. 4, pt. 6, Berlin, 1890. 
La triple división mencionada ahí, se encuentra en Tópicos VIII, 11, 162 a 15-18: "El filosofema es un razonamiento demostrativo, el epiquerema, un razonamiento dialéctico, el sofisma; un razonamiento erístico, y el aporema, un razonamiento dialéctico de contradicción". No debe asombrarnos que la retórica aparezca como asilogística. Recuérdese que el entimema ha sido excluido de Tópicos. Al hablar de Retórica y Poética como asilogísticas, Amonio está refiriéndose, sin embargo, a una forma argumental. El entimema no nos presenta todas las premisas y, por ello, lo más común es referimos a él como un silogismo abreviado.

En el capítulo cuarto del Peri Hermeneias, Aristóteles afirma que los discursos no apofánticos no pueden clasificarse según su verdad o falsedad y, por eso, parece que están fuera de la lógica. El Estagirita termina diciendo que por no ser verdaderos ni falsos, serán estudiados en la Retórica y la Poética, no en Peri Hermeneias ${ }^{10}$. Amonio interpreta que ambos discursos; el apofántico y el no apofántico, se relacionan con el lenguaje: uno con los discursos que se dan ante un auditorio (no apofántico), el otro con lo que las cosas son en sí mismas y lo que las palabras significan (el apofántico). El primero es el del rétor y el poeta porque ambos se relacionan con un auditorio al que hay que persuadir y conmover con lo que se dice. El segundo, el apofántico, es el del filósofo, porque a él le corresponde estudiar la relación que hay entre la palabra y la cosa. De modo que cabría pensar que la división de Amonio está pensada a partir de los distintos usos que puede tener un discurso. $\mathrm{Ha}$ de recordarse que Alfarabi también mostró gran interés en las ciencias del lenguaje y, en particular, en la gramática.

En los comentadores alejandrinos hay distintas aproximaciones al Órganon. Sin embargo, a pesar de las discrepancias que pueda haber entre unos y otros, es común encontrar una división tripartita del Órganon aristotélico ${ }^{11}$. El punto focal en estos esquemas es la lógica

${ }^{10} \mathrm{Cf}$. ARIsTóteles: Peri Hermeneias. 4, 17a 1-8.

${ }^{11}$ Esta división tripartita es similar a la que aparece en el comentario de TOMÁS DE AQUINo a los Analiticos Posteriores: In Aristotelis libros Peri Hermeneias et Posterionum analyticorum expositio, Ed. R. M. Spiazzi, Turin: Marietti, 1955. Además, esta misma división se encuentra en varios alejandrinos. Por ejemplo, en 
como un método concebido estrictamente como la regla del conocimiento apodíctico. Este método tiene tres partes. La primera estudia sus principios: un prerrequisito indispensable es, precisamente, estudiar el propio método. De esto se encargan Categorías, Peri Hermeneias y Analiticos Primeros. La segunda parte es la principal y estudia el silogismo o conocimiento apodíctico como tal, en Analiticos Posteriores. Por último, la tercera parte puede considerarse como un accesorio para los métodos demostrativos. Ésta incluye la mayor parte de los tratados de lógica: Tópicos, Refutaciones Sofisticas y, también, Retórica y Poética. En el caso" de los traductores y comentadores árabes; estos últimos textos se estudiaron antes que los Analíticos Posteriores. Los sirios cristianos que transmitieron la lógica a los árabes sospecharon que la doctrina aristotélica de la ciencia era incompatible con la teología.

Retórica y poética son las formas no apodicticas de razonamiento. Se trata de ramificaciones no demostrativas. Esto no quiere decir que la retórica y la poética estén construidas con falacias y paralogismos. Decir que lo más importante de la lógica es la demostración o apodictica (álta'lím álbr'jany), no quiere décir que no existan otras formas válidas de razonamiento: significa que hay argumentos que operan de un modo distinto, menos riguroso, que son capaces de engendrar alguna convicción.

Entonces habria que plantear si existe un silogismo en los ámbitos no apodícticos $y$, concretamente, en la retórica y la poética. No habria que descartar que ambas fuesen ramas de la dialéctica. Podriamos encontrar similitudes entre los silogismos retóricos y los dialécticos, entre los poéticos y los sofisticos. La retórica podria ser una subclase o una contraparte, una antístrofa - en palabras de Aristóteles- de la dialéctica ${ }^{12}$. En la tradición árabe, como en el

Ammonius: In Categorias Commentarius, ed. A Busse, CAG, vol. 4, pt. 4, Berlin, 1895; 5.6-8; en OLIMPYODORUS: Prolegomena et In Categorias commentarium; Ed. A. Busse, CAG, vol. 12, pt. 1, Berlin: Reimer, 1902, 8.4-10; en Elias:In Aristotelis Categorias commentarium, Ed. A. Busse, CAG, vol. 18, pt. 1., Berlin: Reimer, 1900, 116.29-35; en PHILOPONUs: In Aristotelis Categorias commentarium; Ed. A: Busse, CAG, vol. 13, pt.1., Berlin, 1888, 5.8-14.

12 Cf. ARISTÓTELES: Retórica I, 1354 a 1. 
aristotelismo, los silogismos propios de la retórica son el entimema y el paradigma ${ }^{13}$. En el caso de la poética, Alfarabi apunta la posibilidad de un silogismo poético. En ello radica su innovación interpretativa. En el silogismo poético es muy relevante el papel de la imaginación (tajáy yulun $)^{14}$. Se explicará más adelante que la característica principal del discurso poético, además de su rítmica y musicalidad, es la evocación de imágenes ( $m$ 'tálát). En ello fueron insistentes Alfarabi y, posteriormente, Avicena ${ }^{15}$.

El interés por estudiar las caracteristicas de la argumentación y, en concreto, de los argumentos retóricos y poéticos reaparece, pues, en algunos intérpretes árabes. Desde el año $450 \mathrm{~d}$. C., los sirios tradujeron algunos textos sobre teología $\mathrm{y}$, además, los seis tratados aristotélicos de lógica. Éstos les interesaban por dos razones: primero, porque eran útiles para argumentar en los debates teológicos; segundo, porque estaban interesados en la medicina y, en ese entonces, la más avanzada era la de Galeno, vinculada con la lógica.

Después de una larga historia de expansión musulmana, al norte de Siria se produjeron copias de traducciones de la Introducción a las Categorías de Aristóteles de Porfirio, de las Categorias, el Peri Hermeneias y los Analíticos Primeros. Los cristianos orientales adoptaron varios planteamientos del neoplatonismo alejandrino, en especial de Amonio y Filopón. Por ejemplo, organizaron el estudio

${ }^{13}$ Cf. AlfaraBi: Kitäb al-Hatäba, en Deux Ouvrages Inédits sur la Réthorique, publicación preparada por J. Langhade y M. Grignaschi, Beirut: Dar El-Machreq Éditeurs, 1986.

${ }^{14}$ Cf. LóPEZ-FARJEAT, L. X.: Teorias aristotélicas del discurso, Pamplona: EUNSA 2002, pp. 237-289. También López Farjeat: "El silogismo poético y la imaginación en Alfarabi", en Tópicos, revista de Filosofia de la Universidad Panamericana, núm. 18, México, 2000, pp. 97-113. Éste último, es un articulo al que actualmente incorporo algunas modificaciones, pues he ido descubriendo algunas imprecisiones conforme avanzo en mis investigaciones sobre Alfarabi. En Teorias aristotélicas opté, erróneamente, por vincular el silogismo poético con un entimema. Como mencionaré en este articulo, todo indica que se aproxima más a un paradigma.

${ }^{15}$ Cf. Avicena: Al-Chifa' (La logique. 9. La Poetique), texto árabe presentado por A. Badawi, Comité pour la Commémoration du millénaire d'Avicenne, El Cairo, 1966. 
de la lógica en nueve materias: 1) Introducción a las Categorías; 2) Categortas; 3) Peri Hermeneias; 4) Analiticos Primeros; 5) Analiticos Posteriores; 6) Tópicos; 7) Refutaciones Sofisticas; 8) Retórica; 9) Poética.

De la tradición siria y cristiana, el mundo árabe heredó varios aspectos transmitidos por las escuelas de Bagdad y Jundishapur: 1) dividieron la lógica en nueve ramas; 2) valoraron los comentarios de alejandrinos neoplatónicos y adoptaron su método de trabajo; 3) también por influencia neoplatónica, intentaron reconciliar el platonismo y el aristotelismo ${ }^{16}$; 4) enseñaron a los estudiantes de Filosofia los primeros cuatro tratados del Órganon evitando, como se ha dicho, la lectura de los Analiticos Posteriores; 5) se promovió el estudio de la lógica como la preparación para saberes avanzados como la ciencia, la medicina y la teología.

Entre los años 900 y 1000 un grupo de traductores mejoró las versiones del Órganon dando a conocer, por fin, los Analíticos Posteriores. En este grupo destaca Abu Bishr Matta de Bagdad (870940), quien tradujo y comentó casi todo el Organon. Este traductor estaba más familiarizado con el árabe. Toda la primera generación de lógicos y filósofos islámicos trabajaron con sus traducciones e incluso Alfarabi fue su discípulo.

\section{Los tratados de lógica en el lḥ̦ạa' al-'ulūm}

Uno de los trabajos más importantes de Alfarabi es su $I h s \bar{a}^{\prime}$ al'ulūm ${ }^{17}$. Ahi aparece el siguiente índice:

\section{Artículo I}

Sobre la ciencia del lenguaje.

${ }^{16}$ Así lo intenta también Alfarabi. Cf. Alfarabi's Philosophy of Plato and Aristotle, New York: Free Press of Glencoe, Macmillan Co. 1962.

${ }^{17} \mathrm{Cf}$. Alfarabl: Catálogo de las Ciencias, edición y traducción de Ángel González Palencia, Madrid-Granada: Consejo Superior de Investigaciones Científicas 1953. 


\section{Artículo II}

Sobre la utilidad de la lógica

\section{Artículo III}

De la ciencia de las matemáticas

\section{Artículo IV}

Sobre la ciencia fisica y la ciencia metafisica

\section{Artículo V}

Sobre la ciencia política, la ciencia del derecho y la teología

Me centro únicamente en el Artículo II. Para Alfarabi existen cinco artes lógicas. Independientemente de la necesidad de conocer todo el Órganon, al hablar de argumentación, Alfarabi se interesa en Analíticos Posteriores, Tópicos, Refutaciones Sofisticas, Retórica y Poética: En cada uno de estos tratados se estudia un arte lógico o argumentativo distinto. Escribe Alfarabi:

Las partes de la lógica son ocho. En efecto: las especies de silogismo y las especies de elocución que pueden emplearse para demostrar una opinión :o cuestión cualquiera, y las especies de las artes cuya función propia (cuando son perfectas) consiste en servirse del silogismo elocutivo, pueden reducirse, en suma, a cinco: apodicticas, polémicas, sofisticas, rètóricas y poéticas ${ }^{18}$.

Más adelante explica el contenido de cada uno de los ocho libros de lógica y muestra en cuál de ellos se encuentra cada silogismo y especie de elocución:

Libro $1^{\circ}$, que contiene los cánones de las ideas aisladas y de las palabras que las expresan. Este libro es el titulado en árabe al-maqülāt (Los predicamentos), y en griego

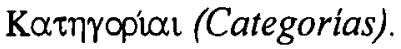

${ }^{18}$ Alfarabi: Catálogo de las Ciencias, ed. cit., pp. 25-26. 
Libro $2^{o}$, que contiene los cánones de las elocuciones simples, las cuales constan de dos solas ideas aisladas o de las dos palabras que las expresan. Este libro se titula en árabe al- 'ibāra ( $\mathrm{La}$ interpretación), y en griego

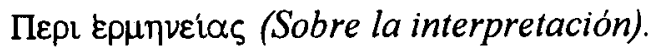

Libro $3^{\circ}$. que contiene los cánones, mediante los cuales se aquilata el valor de las especies de demostración comunes a las cinco artes demostrativas. Este libro se titula en árabe $a l$ -

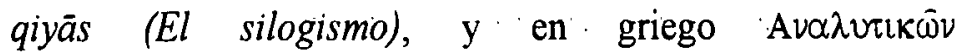

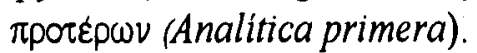

Libro $4^{\circ}$, que contiene los cánones, mediante los cuales se aquilata el valor de las elocuciones apodícticas y aquellos por los que se rige la sistematización de los problemas de la filosofia para que sus investigaciones tengan el éxito más perfecto, más excelente y más completo. Este libro se titula en árabe Kitāb al-burhän (Libro de la demostración

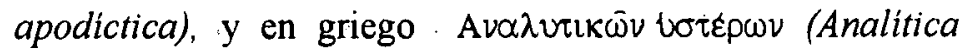
segunda).

Libro $5^{\circ}$, que contiene los cánones, mediante los cuales se aquilata el valor de las elocuciones polémicas, el método de la objeción y de la respuesta dialécticas y, en suma, los cánones por los que se rige la sistematización del arte de la controversia para que sus. operaciones todas resulten lo más perfectas, excelentes y eficaces que sea posible. Este libro se titula en árabe Kitāb al-mawādi 'i al-yâdabiyya (Libro de los lugares dialécticos). y en griego Tonık̄̄v (Lugares o Tópicos).

Libro $6^{\circ}$, que contiene primeramente los cánones para el uso de los medios, cuya función propia es extraviar al entendimiento del camino de la verdad, engañarlo y dejarlo perplejo. En él se enumeran todos los recursos de que se sirve el que se propone alterar la verdad y falsificarla sutilmente en los conocimientos y en las elocuciones. 
Después enumera además los necesarios para encontrar esas elocuciones sofisticas de que se sirve el falsario y el farsante; explica cómo se resuelve y qué es lo que debe recusarse y cómo ha de preservarse el hombre de caer en un sofisma en sus investigaciones o de inducir a error a los demás. Este

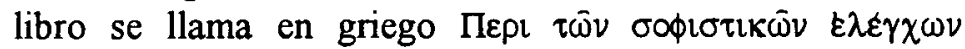
(Sofistica), que quiere decir la sabiduría falsificada.

Libro $7^{\circ}$, que contiene los cánones mediante los cuales se examina y aquilata el valor de las elocuciones retóricas, de las varias especies del discurso oratorio, de las maneras de hablar empleadas por los literatos y oradores, a fin de averiguar si se acomodan o no al método propio de la retórica. En dichos cánones se enumeran todos los elementos que contribuyen a integrar el organismo del arte de la retórica, dando a conocer la manera artificiosa de componer en cada materia las elocuciones de este arte y los recursos por los cuales haya de resultar lo más excelente y perfecto que sea posible, y sus operaciones lo más eficaces y elocuentes que quepa. Este libro se llama en griego

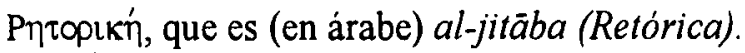

Libro $8^{\circ}$, que contiene los cánones mediante los cuales se someten a examen las poesias y las elocuciones poéticas artificiales en general, y aquellas que particularmente se componen para cada género poético según las materias. En esos cánones se enumeran todos los elementos que integran el organismo del arte de la poesia, 'cuántas son sus partes, cuántas clases hay de poesias y de elocuciones poéticas, cuál es la manera artificiosa para componer cada una de ellas, con qué recursos se puede contar para su composición, cómo se consigue que la poesía sea un todo orgánico, y que resulte dotada de la mayor belleza, énfasis, brillo y gusto posibles y, en fin, qué cualidades debe reunir para que su elocuencia produzca el efecto máximo. Este libro se llama en griego 


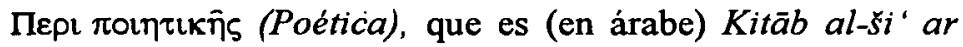
(Libro de la poesia) ${ }^{19}$.

En resumen, si nos concentramos en las formas silogísticas podemos establecer que la primera forma argumentativa trata sobre la convicción y la certeza, y es la demostración (šarhun). La segunda solamente consigue una convicción que nos aproxima a la certeza, y es la dialéctica (tahlilun mantiqiy'yun). La tercera es la sofistica (mantiqiy' yatun), el arte de hacer creer al interlocutor que uno es sabio y conocedor. La cuarta es la retórica ('albalágatu) 0 arte de la persuasión cuya finalidad es convencer. El último arte es, precisamente, la poesía ('aš'si ' $r u$ ). Su propósito, al menos en el $I h s ̣ \bar{a}$ ' al-ulüm, se reduce hasta aquí a simples consideraciones técnicas que debe tener en cuenta aquél que se propone componer poemas. No obstante, más adelante encontraremos que su propósito es evocar imágenes que son similitudes de las cosas pero no las cosas en sí mismas. Puede analizarse con más detalle cada una de estas formas. Alfarabi distingue cada una de ellas considerando la composición de sus premisas, el campo gnoseológico que abarcan y su objeto:

\section{a) La demostración}

En la Risālah Alfarabi anota que "El discurso filosófico se denomina demostrativo. Busca enseñar y hacer clara la verdad en las cosas que son tales que arrojan cierto conocimiento"20. Alfarabi considera que la demostración es la más elevada y noble de las cinco artes lógicas porque conduce a la certeza. El objeto de la demostración es comunicar un conocimiento certero o necesario (darúriy'yun) sobre la existencia y las causas de lo real. La certeza gnoseológica de la demostración no sé reduce al acto de entender, sino también a la capacidad para comunicar lo certero y evidente. Escribe Alfarabi:

${ }^{19}$ Alfarabi: Catálogo de las Ciencias, ed. cit., pp. 32-35.

${ }^{20}$ ALFARABI: Introductory Risalah on Logic, The Islamic Quarterly 3, 1956-1957, p. 231. 
Las elocuciones apodicticas son aquellas cuya función consiste en producir un conocimiento cierto acerca de la cuestión cuya resolución se busca; y esto, tanto si el hombre las emplea dentro de su propio espiritu para investigar él mismo dicha cuestión, como si se sirve de ellas para demostrársela a otro, como si otro lạs usa para demostrársela a él. En todos estos casos la función propia de tales elocuciones es dar por resultado un conocimiento cierto. El conocimiento es cierto, cuando lo conocido no cabe absolutamente que sea de otro modo; cuando no cabe en modo alguno y por ninguna causa que el hombre que lo posee se retracte de él, ni que él mismo conciba como posible tal retractación; cuando no cabe que le ocurran sospechas de error, ni le venga a las mentes sofisma alguno que le obligue a rechazar lo que ya conoce, ni dudas ni conjeturas ${ }^{21}$.

\section{b) La dialéctica o elocuciones polémicas}

Es el arte que engendra una convicción cercana a la certeza. A este tipo de convicción Alfarabi le llama "creencia" (áląn). Alfarabi asume la posición aristotélica descrita en los Tópicos, según la cual la dialéctica es un proceso de discusión que tiene lugar al menos entre dos contrincantes: uno cuestiona y el otro contesta. Quien pregunta intenta refutar la posición del cuestionado y éste responde procurando resistir las objeciones de su contrincante. Las premisas de la dialéctica son las opiniones generalmente aceptadas y las opiniones aceptadas por autoridad. En el primer caso, el de las opiniones generalmente aceptadas, la fuerza de una convicción radica en el testimonio o el criterio de la mayoría: algo pasa como verdadero porque la mayoría opina que ha de ser así. Escrịbe Alfarabi:

Las elocuciones polémicas se emplean en dos casos: $1^{\circ}$, cuando uno arguye con afirmaciones de común sentir, de

${ }^{21}$ AlfaraBi: Catálogo de las Ciencias, ed. cit., p.26. 
ésas que todos los hombres admiten, tratando sólo de vencer al adversario sobre una tesis de cuya verdad éste responde, o defender contra él otra tesis con afirmaciones de aquel mismo género. Si el que arguye se propone vencer al defensor, pero con afirmaciones o medios que no sean de común sentir; y si el defensor intenta sostener su tesis o propugnarla, pero con afirmaciones que no sean tampoco de común sentir, entonces la función de ambos no pertenece al método polémico; $2^{\circ}$, cuando el hombre se sirve de afirmaciones de común sentir como medios para sugerir sospechas vehementes de error en su propio ánimo o en el de otra persona, respecto de una opinión cuya verdad intenta comprobar, llegando hasta imaginar que es cierta, sin que en realidad lo sea ${ }^{22}$.

\section{c) La sofistica}

Es un arte lógico que hace pasar las opiniones generales por silogismos. El sofista es lo suficientemente hábil para presentar una opinión de manera que pueda parecer versado en la materia sobre la que habla ${ }^{23}$ :

Las elocuciones sofisticas son aquellas cuya función propia consiste en inducir a error al entendimiento, extraviarlo y confundirlo, a fin de que llegue a sospechar que es verdad lo que no lo es y reciprocamente; que es un eminente sabio el que no lo es en realidad; y que no es un filósofo verdadero y un sabio el que realmente lo $\mathrm{es}^{24}$.

Las premisas que se usan en la sofistica parecen ser familiares para todos, pero no es asi. El sofista utiliza opiniones generalizadas que llegan a confundirse con universales, pero que en realidad tienen una

${ }^{22}$ Alfarabi: Catálogo de las Ciencias, ed. cit., pp. 26-27.

${ }^{23}$ Cf. FUAD SAID HADDAD: Alfarabi's Theory of Comunication, ed. cit., pp.111-113.

${ }^{24}$ Alfarabi: Catálogo de las Ciencias, ed. cit., pp. 27. 
parte de falsedad que queda disfrazada porque la mayoria las acepta. No obstante, la diferencia que existe entre un sofista, un dialéctico y un retórico no se define tan claramente por la estructura de sus silogismos, sino por su intención y su objetivo. En este sentido, el objetivo de un sofista es el engaño. Por ello, la sofística puede producir falsas creencias. Por estas razones, Alfarabi afirma que:

El discurso sofistico busca superar al interlocutor por una supuesta victoria en las cosas que son pensadas como ostensiblemente sabidas, sin ser así. Su objetivo es empujar al interlocutor y a los oyentes al error, así como a la falsificación y el engaño, y que el orador debe producir la opinión sobre sí mismo de que es alguien que posee la sabiduria y el conocimiento, sin ser así. Por ello, el nombre de ese arte se deriva de la falsa sabiduria de la que se piensa que es sabiduria, sin ser así; viz., sophia, sabiduria, e istes, falsificación ${ }^{25}$.

\section{La función de la retórica y la poética}

Sobre el discurso retórico y el poético pueden leerse algunas consideraciones en varios textos de Alfarabi. Recurriré a las que aparecen en el Ihșā' al-ulüm y a las de la Risälah. Sin embargo, me centraré especialmente en la explicación que aparece en los Fusul [al- 'ilm] Al-Madani porque ahi se destaca una curiosa diferencia entre estos dos discursos, a saber, la distinción entre asentimiento y simple disposición. Viene al caso, pues, en primer lugar, recordar la explicación del Ihșẫ' al-úūm:

Las elocuciones retóricas son aquellas cuya función propia consiste en conseguir persuadir al hombre acerca de cualquier opinión, haciendo que su espíritu se incline a confiar en la verdad de lo que se le dice y otorgar a ello su asentimiento, con intensidad mayor o menor; porque las adhesiones fundadas en la mera persuasión, si bien son

${ }^{25}$ ALFARABI: Introductory Risalah on Logic, ed. cit., p. 231. 
inferiores en intensidad a la opinión muy probable, admiten entre sí varios grados, siendo unas más firmes que otras, según que lo sean las elocuciones que las producen, puesto que, indudablemente, ciertas elocuciones persuasivas son más eficaces, más elocuentes, más fidedignas que otras; lo mismo ocurre con los testimonios: cuantos más en número, tanto más elocuentes y eficaces son para persuadir y convencer de la verdad de una noticia y para obtener un asentimiento más firme respecto de la verdad de aquello que se dice. Mas, a pesar de esta variedad de grados en la intensidad de la persuasión, ninguna de las elocuciones retóricas puede llegar a producir el asenso propio de la opinión muy probable, próxima a la certeza. Y en esto se diferencia, bajo este respecto, la retórica de la polémica ${ }^{26}$.

Hasta aquí la explicación sobre la retórica. Las premisas de la retórica pueden versar sobre cualquier tema y con ellas se intenta hacer que un sujeto se incline hacia cierta creencia. Se admiten, según Alfarabi, distintos grados de persuasión porque han de tenerse en cuenta distintos factores: la fuerza de la elocución, los testimonios, etcétera. Aunque en este pasaje Alfarabi no lo menciona, ha de tenerse en cuenta, incluso, el talante del orador. Un buen retórico trata de obtener un asentimiento lo más firme posible. Más adelante, observaremos que este aspecto es importante en los Fusul. Se suma una cuestión más que merece comentarse, a saber, la diferencia entre retórica y dialéctica. Según Alfarabi, mientras que la dialéctica podría engendrar una opinión muy cercana a la certeza, no sucede lo mismo con la retórica. A mi parecer, esta distinción no es clara y planteada de esa manera en vez de atender a la fuerza argumentativa o a los usos silogísticos, es muy discutible. Si bien un argumento dialéctico puede ser más firme desde el punto de vista lógico, uno retórico puede ser más persuasivo. La versatilidad de un retórico y su habilidad para tener en cuenta los factores emocionales pueden permitirle una capacidad mayor para que alguien crea que una opinión es cercana a la certeza, aun cuando los versados en lógica pueden percatarse de que no es así.

${ }^{26}$ AlfaRABI: Catálogo de las Ciencias, ed. cit., p.29. 
Comentemos ahora las líneas dedicadas a la poética:

Las elocuciones poéticas son aquellas que se componen de elementos cuya función propia consiste en provocar en el espíritu la representación imaginativa de un modo de ser o cualidad de la cosa de que se habla, sea esta cualidad. excelente o vil, como, por ejemplo, la belleza, la fealdad, la nobleza, la abyección u otras cualidades semejantes a éstas. Al escuchar las elocuciones poéticas, nos ocurre, por efecto de esa sugestión imaginativa que en nuestros espíritus provocan algo análogo a lo que nos pasa cuando miramos un objeto parecido a otro que nos repugna, porque inmediatamente que lo miramos, 'la imaginación nos lo representa como algo que nos disgusta, y nuestro espíritu se aparta y huye de él, aunque estemos bien ciertos de que el tal objeto no es en realidad tal como nos lo imaginamos. Así, pues, aunque sepamos que lo que nos sugieren las elocuciones poéticas respecto de un objeto no es tal como ellas nos lo sugieren, sin embargo obramos tal y como obraríamos si estuviésemos seguros de que es asi, porque el hombre muchas veces obra en consecuencia de lo que imagina, más que siguiendo lo que opina o sabe; y muy a menudo resulta que lo que opina o sabe es contrario a lo que imagina, y en tales casos, obra conforme a lo que imagina y no según lo que opina o sabe. Esto mismo nos ocurre cuando miramos a las imágenes representativas de una cosa o a los objetos que se parecen a otro.

Las elocuciones poéticas se emplean únicamente cuando se dirige la palabra a un hombre a quien se le desea excitar a que haga una cosa determinada provocando en su espíritu una emoción o sentimiento e inclinándole así con arte a que la realice. Mas esto no puede ser sino en dos hipótesis: o cuando el hombre ese a quien se trata de inducir es un hombre falto de reflexión para dirigirse por ella, y, por tanto, tiene que ser excitado a obrar lo que se le propone por medio de la sugestión imaginativa, la cual hace para él las veces de la reflexión; o cuando se trata ya de un hombre dotado de 
espiritu reflexivo, pero se quiere conseguir de él que realice algún acto que, si él lo examina reflexivamente, no es seguro que lo haga; y en este caso se le aborda de improviso con frases poéticas a fin de que la sugestión imaginativa preceda a su reflexión y se lance de este modo, por la precipitación, a realizar aquel acto, antes de que la reflexión acerca de sus consecuencias le hagan retractarse de su propósito y se abstenga en absoluto de realizarlo o se decida a no apresurarse y a dejarlo para más adelante, en vista de la conveniencia de estudiarlo detenidamente. Por esta razón, las elocuciones poéticas son las únicas que se presentan hermoseadas, adornadas, llenas de énfasis y redundancias, pulidas con el esplendor y brillo que proporcionan los recursos de que trata la ciencia de la lógica ${ }^{27}$.

En este pasaje destaca la capacidad del discurso poético para generar una especie de afección emotiva en el alma valiéndose de una representación. Cuando esto sucede, podemos actuar conforme a los dictados de la imaginación y no de acuerdo con la realidad. Hay una cuestión relevante a este respecto: la acción. Alfarabi hace ver que este discurso es útil cuando queremos que alguien actúe de manera determinada. En otras palabras, los discursos poéticos conducen a la acción. Esta es la razón por la que son útiles en la educación de las personas. Al mismo tiempo, habría que ser cuidadoso con las representaciones porque, como se ha explicado, éstas poseen una capacidad sugestiva que resulta determinante al momento de actuar. En este pasaje Alfarabi se refiere una vez más a la capacidad de la elocución poética para incitar a la acción.

Me refiero ahora a las descripciones de la retórica y la poética que aparecen en los Fusul [al- ' $\mathrm{ilm}$ ] $\mathrm{Al}$-Madani. Se lee en el aforismo 54:

La retórica es la capacidad de hablar por medio de locuciones, por la que se da excelencia en persuadir sobre algunas de las cosas posibles cuya naturaleza consiste en ser

${ }^{27}$ Alfarabi: Catálogo de las Ciencias, ed. cit., pp.29-31 
elegidas o evitadas. Sin embargo, el virtuoso que posee esta facultad se sirve de ella para las buenas acciones, mientras que el astuto se sirve de ella en las malas.

La retórica no tiene un objeto definido, pero es útil para cualquier tópico. Su campo de acción es entonces muy amplio. Sus premisas son, como en la dialéctica, las "cosas posibles (mumkinun) cuya naturaleza consiste en ser elegidas o evitadas". Cuando una de estas opiniones alcanza tal grado de verosimilitud que casi se confunde con lo verdadero, entonces es útil para el retórico, no por su cercanía a la verdad, sino por su aceptación generalizada. He aqui el gran parecido con la dialéctica. El propósito de la retórica es persuadir. La persuasión engendra una creencia con respecto a algo necesario o plausible. La plausibilidad que utiliza un retórico para engendrar una creencia no apunta a la esencia de las cosas, sino a un estado de la mente en el que podemos llegar a creer algo independientemente de que no tengamos ninguna certeza de ello.

Como se sabe, la persuasión retórica está basada en el uso de entimemas y paradigmas. Los retóricos no son solamente argumentativos sino que sus razonamientos también apelan a la emoción de los oyentes (ira, gratitud, simpatía, descortesia). Este último es un recurso muy efectivo. En la descripción de los Fusul [al- 'ilm] Al-Madani se agrega la doble cara de la Retórica: si el retórico es virtuoso, persuade al bien; si es perverso, seduce hacia el vicio. Con ello, Alfarabi concede un espacio a la retórica ante quienes piensan en su parentesco con la sofistica.

En el aforismo 55 de los Fusul [al-'ilm] Al-Madani se lee:

La excelencia en poder evocar imágenes [es decir, la poética] es distinta de la excelencia en persuadir. La diferencia entre ellas consiste en que con la excelencia en persuadir se intenta que el oyente haga algo después de asentir a ello, y con la excelencia en poder evocar imágenes se pretende excitar en el alma del oyente el deseo de lo imaginado y huir de ello, o tender hacia ello o aborrecerlo, aunque no haya asentimiento, como cuando un hombre 
detesta algo al ver que se parece a lo que de verdad detesta, aunque esté cierto de que lo que ve no es aquello mismo que detesta.

La excelencia en poder evocar imágenes es empleada en lo que causa indignación y satisfacción, miedo y confianza, en lo que aplaca o endurece el alma, y en las restantes afecciones del alma. Con la excelencia en poder evocar imágenes se pretende inducir al hombre a aceptar algo y a ir hacia ello, aunque su conocimiento de eso precise de lo contrario de lo que se le ha evocado en su imaginación. La mayoria de los hombres sólo aman y odian algo, sólo lo eligen y lo rechazan, por la imaginación, no por la deliberación, sea porque carecen de deliberación por naturaleza o porque la han rechazado en sus asuntos.

En la primera parte de este aforismo aparece una diferencia importante entre la retórica y la poética: la primera persuade y, por tanto, consigue el asentimiento del oyente y lo incita a la acción. Por ello, Alfarabi le otorga un lugar importante en sus artículos de ciencia política. La noción de "asentimiento" (tạsdīq) es innovadora en la interpretación farabiana y es posible que la haya adoptado de la lógica estoica ${ }^{28}$. Retórica y poética tienen en común su capacidad para inducir a la acción. Sin embargo, la retórica podría conseguir el 'asentimiento' de una creencia, es decir, la habilidad de un rétor consistiria en hacer que alguien admitiera algo como cierto. En cambio, al referirse a la poética, Alfarabi le concede una función pedagógica, pero en ese caso se trata de despertar en el alma ciertas emociones sin necesidad del asentimiento del oyente. Un poeta provoca la atracción o el rechazo hacia algo a través de su representación. Por esta razón, en el aforismo 56 de los Fusul [al'ilm] Al-Madani, Alfarabi explica por qué las imágenes poéticas pueden mejorar y corregir las afecciones del alma ${ }^{29}$.

28 Cf. López Farjeat, L. X.; SÁNCHEZ, M. T.: Analogía poética en Alfarabi, promanuscrito, 2002.

${ }^{29}$ Cf. AlfaraBi: Fusul [al- 'ilm] Al-Madani 56. Alfarabi afirma ahí la existencia de seis tipos: de poesia: Los tres primeros están aprobados porque sirven para enaltecer la virtud; los otros tres están censurados porque promueven el vicio. 
El rechazo de un vicio o la aceptación de una virtud a través de las imágenes poéticas no implican necesariamente un asentimiento. El retórico consigue el asentimiento acudiendo a una serie de argumentos persuasivos. Todo indica que los argumentos retóricos permiten cierta acción deliberativa. Ante un discurso retórico, el oyente sopesará las razones ofrecidas en el argumento retórico y conciuirá actuando conforme a la opción más convincente para él. En cambio, la poesía dispone al oyente excitando en su alma el deseo o la aversión por vía imaginativa y omitiendo cualquier proceso deliberativo. Podriamos decir que Alfarabi concede cierto poder a las imágenes poéticas al proponer que los poemas se dirigen a la imaginación y no a la razón deliberativa. Habria que determinar entonces cuál es el papel de la imaginación y su relación con el discurso poético.

\section{El silogismo poético y la imaginación}

La posibilidad del silogismo poético resulta polémica. En la Poética, Aristóteles nunca utiliza la expresión 'silogismo poético'. Alfarabi entiende, observa Salim Kemal, que el discurso poético es imaginativo, asocia imágenes y representaciones $\mathrm{y}$ produce sentimientos. Se caracteriza por estar vinculado con la imaginación. Alfarabi se refiere a esa facultad en los siguientes términos:

La [facultad] imaginativa (al-quwwa al-mutajayyila) es la que conserva las impresiones de los sensibles después de haber desaparecido el ejercicio de los sentidos sobre ellos. Combina unos con otros de muy diversas maneras y separa unos de otros de muchas y diferentes formas, unas verdaderas y otras falsas, tanto durante la vigilia como durante el sueño ${ }^{30}$.

Aristóteles, por su parte, se refiere a la imaginación en De anima. En III, 428 a 1-5 explica que en primera instancia, la imaginación sería el proceso por el cual decimos que una imagen está presente en

${ }^{30}$ Alfarabi: Fusul [al- ilm] Al-Madani 7. 
la mente $y$, por tanto, podría servirnos para juzgar y discernir entre lo verdadero y lo falso, tal como lo haríamos con las siguientes potencias: aisthesis, epistéme, nous, y dóxa. No obstante, Aristóteles se dedica a distinguir a la imaginación de cada una de éstas:

a) La imaginación no es atsthesis porque" se da independientemente de que la señsación esté en potencia o en acto, es decir, 'aunque toda imagen sé produce a partir de los sentidos, cuando la sensación está en potencia, la imaginación puede actuar con autonomía;

b) La imaginación tampoco puede ser epistéme o nous porque se trata de facultades que son siempre verdaderas y, en cambio, 'el valor veritativo de la imaginación es ambiguo y exige matices;

c) La imàginación ni siquiera es dóxa porque ésta va acompañada de convicción y existen animales con imaginación y sin convicción.

En De anima III, 428 b 1-16, Aristóteles caracteriza a la imaginación como un movimiento que se produce a partir de la sensación. Alfarabi recurre a esta misma idea è insiste también en que la imaginación ha de situarse entre la sensación y la razón. Le atribuye, además, la capacidad de recibir, componer y dividir imágenes. Pero también le asigna una función más, a saber, la mimesis (muhâkâ). Alfarabi escribe en La ciudad ideal: "Junto con la conservación de las impresiones sensibles y la combinación de unas con otras, tiene una tercera operación: la imitación"31. Precisamente el discurso poético es imitativo.

Salim Kemal expone las tres caracterizaciones del discurso poético que aparecen en Alfarabi ${ }^{32}$. En éstas se pone especial énfasis en la noción de mimesis. Ésta consiste en una presentación análoga de la

\footnotetext{
${ }^{31}$ Alfarabi: La ciudad ideal, traducción de Manuel Alonso, Madrid: Tecnos 1985, p.74.

32 Cf. KeMAL, S.: The poetics of Alfarabi..., ed. cit., pp. 106-120.
} 
realidad. Ello implica, además de la retención de imágenes, la combinación, separación y recomposición de unas con otras. Estas tres caracterizaciones son las siguientes y en ellas se involucra a la imaginación en el silogismo:

a) Primera caracterización: ésta pertenece a la Risālah. Ahí se afirma que el discurso poético posee una forma silogística y que, aunque no'es demostrativa, usa silogismos. Se dice que a través de imágenes el poeta logra que alguien conciba una imagen $y$, por tanto, su poder radica en la capacidad de la imaginación para retener y manipular representaciones. $\mathrm{El}$ problema es que hay una especie de confusión: silogizar es una capacidad raciocinante y la razón actúa también sobre representaciones de la imaginación. Como Alfarabi no ha distinguido entre las representaciones a las que recurre la razón para demostrar y a las que recurre la poesía, parece que esta explicación todavía es fallida. Alfarabi tendría que explicar la peculiaridad de la representación de la poesia.

b) Segunda caracterización: ésta aparece en los Cánones. Ahí. Alfarabi afirma que el discurso poético no es demostrativo ni argumentativo, no retórico ni sofistico; es imitativo, significante y falso si lo consideramos en su dimensión lógica. No obstante, Alfarabi establecerá que, aunque el discurso poético es lógica y noéticamente falso, es comunicativo.

En términos generales, las palabras pueden tener o no, significado. Las palabras con significado pueden encontrarse en composición. Aquellas en composición pueden formar o no aseveraciones. De las aseveraciones, unas son categóricas $\mathrm{y}$ otras no. De las categóricas unas son verdaderas y otras falsas. De las falsas, unas traen a la mente del escucha el objeto referido como una aseveración directa, mientras que 
otras traen a la mente la imitación del objeto. Éstos son los discursos poéticos ${ }^{33}$.

Si el significado del discurso poético permite cierto tipo de conocimiento, entonces es categórico porque afirma algo y eso ha de hacerlo en alguna forma silogistica. Luego, si es categórico, las representaciones de la imaginación han de tener alguna conexión con la realidad. Esta es la razón por la que el pasaje farabiano en el que se declara la falsedad del discurso poético puede ser cuestionado y puede concluirse, por tanto, que esta segunda caracterización es fallida. Esto no quiere decir que debamos alegar la verdad del discurso poético sino, más bien, plantearnos que posiblemente carezca de valor veritativo. Incluso, si como veremos más adelante, la función pedagógica de este discurso es relevante, luego; el énfasis ha de ponerse en su capacidad persuasiva y moral más que en su valor lógico.

c) Tercera caracterización: ésta también es de los Cánones. El discurso poético es analógico. Eso significa que admite una deducción analógica. Se trata, pues, de' un silogismo en el que opera la generalización y la transferencia de una premisa universal a una particular; ésta a su vez vuelve a transferirse a un universal. Es la misma estructura de un paradigma: si Dionisio pide una escolta, quiere la tirania porque Pisistrato y Teágenes pidieron la escolta y se convirtieron en tiranos (Ret. 1357b 26-38). Asi se ha establecido el carácter silogístico de la poesía. Pero hay un elemento más: como hace notar Kemal, podemos asociar los elementos que intervienen en el silogismo a partir de la imaginación. El discurso poético es, pues, silogístico por el ejemplo o paradigma y se formaliza tal como aparece al final del breve comentario a Analiticos Primeros, a través de una transferencia por analogía. Alfarabi escribe: “(..) el discurso

33 Alfarabi: "Canons of Poetry", texto bilingue y traducción a cargo de. A $L$ Arberry, en Rivista degli Studi Orientali XVII, Università di Roma, Roma, 1938, p. 273. 
poético es aquél que no es demostrativo ni argumentativo ni retórico ni sofistico. No obstante, pertenece a cierta especie de silogismo o lo que sigue del silogismo. Por lo que sigue, quiero decir, deducción, imagen, intuición o algo simịlar con la misma fuerza que una analogía" ${ }^{34}$. Aunque bastante ambiguo, este pasaje destaca el carácter analógico del silogismo poético: Enumerar juntos una deducción; una intuición y una imagen no aclara demasiado. No obstante, creo que lo que podría interpretarse es que Alfarabi intenta rescatar la inteligibilidad del discurso poético.. El discurso poético es silogístico porque discurre a través de un paradigma. En el paradigma hay una sucesión inteligible entre las premisas que conducen a una conclusión a través de una transferencia analógica.

La condición analógica del discurso poético es complicada en la descripción que aparece en los Cánones. Por ejemplo, Alfarabi explica que "(...) La aseveración analógica puede ser potencial.o actual. La potencial puede ser deductiva $\circ$ mimética. La mimesis es generalmente usada en el arte de la poética. Por ello, es claro que el discurso poético es una mimesis" 35 . Alfarabi concede importancia a la analogía para el conocimiento de los inteligibles. Esto es, quizá, lo que quiere decir cuando habla de una aseveración analógica actual. Sin embargo; ha de hacerse notar que éste es un aspecto controvertido del que no me haré cargo. Anoto, sin embargo, el pasaje en donde Alfarabi se expresa al respecto:

(...) del entendimiento agente viene unas veces a la imaginativa cierta emanación y el entendimiento agente realizará entonces en ella una acción que proporcionará aquellos inteligibles de cuya naturaleza es que se produzcan en la razón especulativa, otras veces presentará los objetos particulares sensibles de cuya naturaleza es que se produzcan en la razón práctica. De este modo la imaginativa recibirá los inteligibles mediante las representaciones e imitaciones

34 Alfarabi: “Canons...”, ed. cit., p. 274.

35 AlfaraBI: “Canons...”, ed. cit., p. 274. 
sensibles que ella misma compuso y recibirá los objetos particulares, unas veces imaginándolos como ellos son en sí, $\mathrm{y}$ otras imaginándolos mediante otras imitaciones 0 representaciones sensibles ${ }^{36}$.

Enseguida Alfarabi comenta que la intervención del, intelecto agente en la imaginación se da, por lo general, durante el sueño; aunque en el caso de los profetas puede darse en la vigilia. Con el vínculo establecido entre intelecto agente e imaginación, Alfarabi piensa que ha justificado la racionalidad de las revelaciones proféticas.

Considero importante detenerme un poco más en lo que Alfarabi denomina 'aseveración analógica potencial'. Alfarabi menciona que ésta puede ser deductiva o mimética. Al hablar de una : 'analogía deductiva', me parece que se refiere simplemente a una estructura silogística. Ésta es la de la analogía de proporción: A es a B como C a D. Con la analogía mimética podría estarse refiriendo a una analogia de proporción impropia. Ésta tendria la misma estructura silogistica. Sin embargo, mientras que los términos de la analogía propia se relacionan en función de un género común, los de la impropia son de género distinto: Por ello, para establecer la relación entre los términos de una analogía impropia, se requiere descubrir un símil desde la imagen, no desde el género o por el concepto. Por ejemplo, en un poema de Al-Tajal (siglo IX) se lee: "Trajo el vino, y fue como si en su vasija / refulgiera y espumajease el mismo planeta Marte". En este ejemplo se ha establecido un símil entre el vino y el planeta Marte en función de su color y, quizá, a partir de algunos aspectos simbólicos que pueden atribuírseles a ambos.

Es esta comprensión de la función cognoscitiva de la analogía impropia lo que permite a Alfarabi articular un silogismo poético; es decir, si el razonamiento analógico, aun el impropio del discurso mimético, nos permite discurrir de lo más a lo menos evidente -

${ }^{36}$ AlFARABI: La ciudad ideal, ed. cit., pp. 77-78. 
como se señala en Analíticos Primeros ${ }^{37}$-, la poesia admite cierta estructuración lógica. Paradójicamente, esta estructuración no minimiza en lo absoluto el papel de la imaginación en el discurso poético; por el contrario, permite que los efectos anímicos de las imágenes poéticas sean articulados y dirigidos con cierto grado de inteligibilidad. Para que las imágenes -incluso las oníricas y las proféticas - tengan una resonancia ética (tal es la pretensión de Alfarabi), un eco en las disposiciones del alma, han de ser en cierto modo inteligibles, aunque no apodícticas.

\section{Conclusiones}

Conviene destacar que en muchas ocasicnes la analogia impropia puede llegar a ser más convincente que un argumento perfecto. Para Alfarabi, la convicción que puede engendrarse a partir de un discurso es sumamente importante porque se trata de conseguir 'estados mentales'. De algún modo, el conocimiento consiste en estos estados mentales: lo apodíctico de la filosofia nos conduce a la certeza; lo dialéctico a la opinión, lo retórico y lo poético a la creencia, aunque con medios distintos (la primera con la elocución y la segunda con las imágenes). El discurso filosófico es demostrativo, aspira al conocimiento cierto y, para ello, se vale de la facultad racional; el poético recurre a la imaginación, una facultad inferior. Por ello, el silogismo poético es imperfecto ante uno demostrativo o apodictico. Sin embargo, no es menos importante ni es tan arbitrario como podria parecer. Todo lo contrario, a pesar de su falsedad lógica los

37 Cf. AlfarabI: Short Commentary on Aristotle's Prior Analytics, edited by Mubahat Turker, Ankara Universitesi, 1958, pp. 93ss. He tomado como fuente primera el texto árabe, aunque lo he confrontado con la traducción al inglés de Nicholas Rescher (Al-Färäbi's Short Commentary on Aristotle's Prior Analytics, University of Pittsburgh Press, 1963). En la primera parte de la sección 8 (266:1618) se lee: "Que una cosa sea conocida por la sensación y que una cierta materia esté en una cierta condición, y que una cierta cosa esté presente en una cierta materia; el intelecto transfiere esta condición o cosa de esta materia [conocida] a otra materia similar [desconocida], y por lo tanto, juzga con respecto a ella [esto es, la otra, materia desconocida] bajo las bases [conocidas]". 
discursos poéticos son legítimos y se ayudan con la dialéctica y la retórica:

Puesto que la dialéctica proporciona una poderosa opinión alli donde las demostraciones proporcionan certeza, o en la mayoria de los casos, y la retórica produce persuasión en la mayoria de los casos en que no hay demostración ni tampoco consideración dialéctica, y puesto que la religión virtuosa no es sólo para los filósofos ni para aquellos cuya situación es comprender filosóficamente lo que se dice, sino que la mayoria de aquellos a quienes se les hace comprender las opiniones de la religión y aceptan sus acciones no están en aquella situación $\longrightarrow$ sea por naturaleza, sea porque se han despreocupado de ello-, no siendo de aquellos que no comprenden las opiniones generalmente conocidas o los argumentos persuasivos, entonces, por esa razón, la dialéctica y la retórica son de gran utilidad para que por medio de ellas, esas opiniones sean auxiliadas cuando se presente quien quiera inducir a error y a equivocación. a sus habitantes por medio de la palabra ${ }^{38}$.

Aunque en este pasaje se habla exclusivamente de la utilidad de la dialéctica y la retórica para hacer accesible la religión virtuosa, me parece que el discurso poético y su capacidad para evocar imágenes son igualmente importantes en vistas de que la religión y la poesía se parecen en cuanto a su capacidad persuasiva. La poética guarda algunas similitudes con la dialéctica y la retórica, aunque también se distinga claramente de ellas. Situar la Poética como parte del Organon (recuérdese la división del $I h s \bar{a}^{\prime}$ al-'ulüm) y la descripción que aparece en los Cánones sugieren la existencia del silogismo poético. Me parece que éste es un tema que permite ahondar en varios tópicos, por ejemplo, en la fuerza de la imaginación y en cómo pueden conseguirse estados mentales a partir de ella, en especial, las creencias o convicciones. Éstas, por lo general, están involucradas con un modo especifico de actuar. El silogismo poético

38 AlfaraBi: Libro de la religión (Kitäb Al-Milla) 3, en Obras FilosóficoPoliticas, ed. cit. 
podría tener la estructura de una analogía impropia. Además, permite interferencias de la imaginación y las emociones. Por ello; desde el punto de vista lógico es débil; desde el punto de vista comunicativo, puede ser el más efectivo. En el caso de la poética la intervención de la facultad imaginativa es determinante. En la filosofia islámica, la imaginación tiene, además de una función epistemológica, una ética. Sobre la primera, baste con decir que su papel es central en la operación gnoseológica porque del sentido común recibe la forma material de los sentidos externos, de la memoria las nociones particulares no sensibles de los objetos externos - como sucede en el caso del miedo que experimenta la oveja ante el lobo. Alfarabi escribe: "La facultad imaginativa es intermediaria entre la sensible y la racional. Cuando los auxiliares de los sentidos sienten en acto y realizan su operación, la facultad imaginativa se comporta pasivamente respecto a ellos, ocupándose de los sensibles que los sentidos le presentan y grabándolos en ella; también se ocupa de servir a la facultad racional" 39 .

En lo que respecta a la función ética de la imaginación, Shams Inati y Elsayed Omran ${ }^{40}$, observan cómo para la mayor parte de los filósofos musulmanes la poesía es un discurso imaginativo capaz de disponer a la acción. Por tanto, en la poesía es determinante el modo en que la imaginación representa un objeto: si lo hace ver como algo agradable, se dispone al alma para dirigirse a él; si la representación es desagradable, el alma se alejará de ella. Esto significa que la imaginación genera deseos y aversiones que, al mismo tiempo, pueden suscitarse conforme a los principios del intelecto práctico o de manera independiente. Cuando la imaginación se guia por los principios del intelecto práctico, la acción humana es racional. Cuando actúa con independencia, la acción humana es ambigua, es decir, se conduce a través de imágenes que, aunque son falsas desde la lógica, podrian contener un valor veritativo cognoscitivo si las comprendemos desde una perspectiva ética-pedagógica: la poesía intenta representar imágenes agradables para disponer a las acciones

${ }^{39}$ AlfaraBi: On the perfect State, ed. cit., p. 210.

${ }^{40} \mathrm{Cf}$. INATI, S., OMRAN, E.: "Literature", en History of Islamic Philosophy, ed. cit., pp. 886-897. 
virtuosas y hacer compatible la presencia de la imaginación y la del intelecto práctico. En este sentido, Alfarabi, al igual que Avicena y Averroes, recupera la función educativa de la poesia: la poesia dispone el alma del modo más efectivo.

Demostración, dialéctica y sofistica utilizan un proceso argumentativo y racional específico. Pero éstas no son la única opción que existe para persuadir ni tampoco para comunicarnos. Existen personas a las que se les incita con mayor fuerza a través de buenas elocuciones o de imágenes. En el caso de la retórica, se recurre a los entimemas y paradigmas. En la poesía se evocan imágenes que, al parecer, solamente disponen al alma.

Es cierto que en ocasiones es más efectivo persuadir con elocuciones o imágenes que con razonamientos demostrativos. $\mathrm{Al}$ hablar de la poesia, Alfarabi explica que existen quienes poseen una imaginación $\tan$ activa que les resulta dificil controlarla ${ }^{41}$. En consecuencia, responden inmediatamente a los dictados de las imágenes que ellos abrigan. La centralidad de la imaginación y de la función mimética son aspectos que le otorgan a la filosofia farabiana una originalidad indiscutible. Con ello, el filósofo árabe se aleja de la mera paráfrasis de Aristóteles.

Lo imaginado es a la poesía como la certeza a la demostración, la opinión a la dialéctica y la persuasión a la retórica. Asi como podemos convencernos por la demostración, la opinión o la persuasión, también hay quienes se convencen por lo imaginado. Lo imaginado, como el conocimiento, las opiniones y las persuasiones, puede incitar a los hombres a varios tipos de comportamientos ${ }^{42}$. El hecho de que lo imaginado incite comportamientos es significativo: la poesia es una de las fuentes que proporciona imágenes mentales que disponen para la acción humana. Según Alfarabi, la poesia dispone; la retórica, en cambio, es capaz de provocar un asentimiento. Estas dos disciplinas resultan insoslayables en la comunicación humana.

${ }^{41}$ Cf. KeMAL, S.: The poetics of Alfarabi and Avicenna, ed. cit., pp. 89-107.

42 Cf. Alfarabl: Fusul [al- 'ilm] Al-Madani 56, ed. cit. 
Copyright of Tópicos. Revista de Filosofía is the property of Universidad Panamericana and its content may not be copied or emailed to multiple sites or posted to a listserv without the copyright holder's express written permission. However, users may print, download, or email articles for individual use. 